УДК 342.9

DOI https://doi.org/10.32837/pyuv.v2i3(28).372

\author{
Б. В. Чернявська \\ orcid.org/0000-0001-8263-7483 \\ аспірантка кафедри адліністративного права \\ юридичного факультету \\ Київського національного університету ілені Тараса Шевченка, \\ юрист Наукового иентру нілецького права
}

\title{
ЮРИДИЧНІ ДЕФЕКТИ У ПРАВОВОМУ ЗАБЕЗПЕЧЕННІ РЕАЛІЗАЦІЇ ПРАВА НА СВОБОДУ ОБ'ЄДНАННЯ У ГРОМАДСЬКІ ОРГАНІЗАЦІЇ В УКРАЇНІ
}

Дефектність права сьогодні є явищем об’єктивно існуючим. На жаль, юридичні дефекти мають вкрай негативний вплив на розвиток конституційного та адміністративного права в цілому і деяких правових інститутів зокрема, але завданням науковців $€$ не лише розуміння проблеми та аналіз законодавства на предмет недоліків і колізій, а й розроблення пропозицій, спрямованих на вирішення існуючих проблем. Так, якщо аналізувати правове регулювання права фізичних осіб на свободу об’єднання у громадські організації в Україні, то можна знайти значну кількість прикладів різноманітних за видами юридичних дефектів.

Варто зазначити, що наразі в Україні провадиться активна робота 3 реформування конституційного та адміністративного права: впроваджується нова термінологія, удосконалюється нормативно-правове регулювання окремих інститутів, здійснюється оптимізація системи державних та муніципальних органів тощо. Усі ці процеси пов'язані із прагненням привести національне законодавство та практику його застосування до міжнародних стандартів. Реалізація права на свободу об'єднання у громадські організації значною мірою залежить від належного нормативно-правового регулювання, у структурі якого важливе місце належить нормам адміністративного права. Проте необхідно зазначити, що ці норми наразі недосконалі. У їхньому змісті є чимало суперечливих положень, які негативно позначаються на рівні реалізації громадянами названого права.

3 огляду на це метою даної статті є аналіз нормативно-правового регулювання права фізичних осіб на свободу об'єднання у громадські організації на предмет виявлення наявних колізій та прогалин і вироблення відповідних рекомендацій, спрямованих на нейтралізацію цих негативних чинників.

Для початку звернемось до теорії права та визначимо, що ми розуміємо під поняттям «юридичний дефект», або "дефект правового регулювання», та на підставі якої класифікації юридичних дефектів ми будемо аналізувати досліджуване нами право. Професор Т.О. Коваленко визначає юридичні дефекти як об'єктивно притаманні сис- темі позитивного права юридичні явища, що виявляються в недоліках, вадах засобів правового регулювання, а також у відсутності чи недостатності зв'язків між ними, які справляють негативний вплив, мають своїм наслідком деформацію правового регулювання відносин, виключають або значно ускладнюють досягнення мети такого регулювання [1, с. 237-238].

Розкриття специфіки юридичних дефектів зумовлює необхідність проведення їх класифікації за різними критеріями. Для аналізу досліджуваного права на свободу об'єднання ми обрали класифікацію за критерієм особливості прояву юридичних дефектів у механізмі правового регулювання, залежно від його елементів.

Першими є юридичні дефекти правових норм, які залежно від їхнього змісту поділяють на логіко-структурні, зокрема це колізії, антиномії (суперечності права), прогалини у праві, зайве (надмірне) дублювання, логічна недосконалість правових конструкцій, незбалансованість законодавчого регулювання окремих правових інститутів; суто технічні помилки та техніко-юридичні, до яких відносяться: дефекти правової термінології, невиправдане використання бланкетних та відсилочних норм, невизначеність та декларативність правових норм, надмірна конкретизація [2, с. $778 ; 2$, с. $7 ; 2$, с. 12$]$.

Отже, перейдемо до аналізу правового регулювання права на свободу об'єднання на предмет наявності юридичних дефектів правових норм. Так, стаття 36 Конституції України закріплює право громадян України на свободу об'єднання в політичні партії та громадські організації для здійснення і захисту своїх прав і свобод та задоволення політичних, економічних, соціальних, культурних та інших інтересів [3]. Процитоване конституційне положення деталізовано на рівні Закону України «Про громадські об’єднання», який, на наш погляд, не повною мірою узгоджується із приписами Основного Закону. Так, Конституцією України закріплено право громадян України «на свободу об'єднання в політичні партії та громадські організації». Як випливає зі змісту статей 36 та 37 Конституції України, тер- 
мін «громадська організація» вживається для позначення будь-якого об’єднання громадян, за винятком політичної партії. Отже, існує загальна категорія - «об’єднання громадян», формами (видами) якого можуть бути політичні партії чи громадські організації. Останні є похідними від загальної категорії та не можуть розглядатися окремо від неї. У свою чергу, громадська організація - це родове поняття щодо конкретних видів громадських організацій, у тому числі для професійних спілок.

Законом України «Про громадські об'єднання», який було прийнято пізніше, вводиться нехарактерне для вітчизняної юридичної науки поняття «громадські об’єднання», що включає два типи утворень - «громадська організація» та «громадська спілка». Це дає нам право стверджувати, що не всі об’єднання громадян потрапляють у розряд громадських об'єднань у розумінні даного Закону. Якщо дія попереднього Закону України «Про об'єднання громадян» поширювалась на суспільні відносини у сфері утворення, реєстрації, діяльності та припинення і політичних партій, і громадських організацій, то нині політичні партії виключено з-під сфери його регулювання. Попередній закон визначав будь-яке об'єднання громадян як громадське формування і як таке, що незалежно від назви (рух, конгрес, асоціація, фонд, спілка тощо) являє собою політичну партію або громадську організацію [4].

$\mathrm{y}$ цій частині не можна не погодитись із думкою Н.П. Гаєвої, яка стверджує, що закони та підзаконні нормативні акти повинні прийматися на основі Конституції та мають відповідати її змісту і термінології, інакше вона просто втрачає цінність свого існування [5, с. 91]. У свою чергу, на думку Н.В. Богашевої, неприпустимою є відмова від конституційної доктрини об’єднань громадян (одна 3 доктринальних новел вищезгаданого Закону) [6, с. 22-26], оскільки це призвело до фактичного виведення 3 юридичного обігу терміна «об'єднання громадян», який закріплено у статті 36 Конституції України.

Отже, як ми бачимо, дефініція, закріплена в Законі України «Про громадські об’єднання», є дещо вужчою: «Громадська організація - це громадське об'єднання, засновниками та членами (учасниками) якого є фізичні особи». Громадським об'єднанням, у свою чергу, законодавець вважає «добровільне об'єднання фізичних осіб та/або юридичних осіб приватного права для здійснення та захисту прав і свобод, задоволення суспільних, зокрема економічних, соціальних, культурних, екологічних, та інших інтересів» [7]. Відтак робимо висновок, що змістовне наповнення категорії «громадська організація» за умови збереження терміна, який їі позначає, кардинально змінює традиційний підхід до неї та потребує пе- реосмислення. Тим не менш, вважаємо за необхідне привести категоріальний апарат, який вживається в законі, у відповідність до Конституції України, де чітко зазначено, що право громадян на свободу об'єднання реалізується через утворення та членство саме у громадських організаціях, а не інших формах об'єднань: формуваннях, асоціаціях тощо.

Ще одне поняття, яке існувало раніше в Законі України «Про об’єднання громадян» (втратив чинність), наразі знову введено законодавцем i має безпосереднє відношення до об'єднань громадян - термін «громадське формування» [4]. Воно 3'явилось у новій редакції Закону України «Про державну реєстрацію юридичних осіб, фізичних осіб-підприємців та громадських формувань» i охоплює своїм змістом політичні партії, структурні утворення політичних партій, громадські об’єднання, місцеві осередки громадського об’єднання зі статусом юридичної особи, професійні спілки, їх об’єднання, організації профспілки, передбачені статутом профспілки та їх об’єднання, творчі спілки, місцеві осередки творчих спілок, постійно діючі третейські суди, організації роботодавців, їх об’єднання, відокремлені підрозділи іноземних неурядових організацій, представництва, філії іноземних благодійних організацій (пункт 3 частини першої статті 1 Закону) [8]. Отже, громадська організація, відповідно до даного закону - також різновид громадського формування, яке $\epsilon$, по суті, тотожним поняттю об'єднання громадян. При цьому, звертаючись до Закону України «Про участь громадян в охороні громадського порядку і державного кордону», ми зустрічаємо поняття громадського формування [9], але в розумінні цього закону воно ніяк не співвідноситься 3 категорією громадської організації, хоча також являє собою громадське об'єднання, створене фізичними особами.

Надмірна конкретизація та невиправдана деталізація моделей поведінки як вид техніко-юридичного дефекту проявляється у формулюванні положення статті 36 Конституції України. Так, на нашу думку, необхідно змінити положення даної статті в частині «захисту своїх прав і свобод», замінивши на формулювання «захисту законних прав і свобод», оскільки це дозволяє створювати громадські організації для захисту інтересів не лише членів даної громадської організації, а й інших осіб, які цього потребують.

Отже, у продемонстрованих вище випадках ми спостерігаємо як логіко-структурні дефекти у вигляді колізій, суперечностей права, так і техніко-юридичні дефекти, що виявляються в дефектах правової термінології, невизначеності правових норм, їхній надмірній конкретизації. Суперечності та розбіжності мали місце в наповненні дефініцій «об’єднання громадян», «громадське об’єд- 
нання», «громадська організація» та «громадське формування».

До другого виду юридичних дефектів відносять дефекти джерел права як форми об’єктивації правових норм. Їх можна визначити як недоліки, вади похідних від держави або визнаних нею офіційних документальних способів вираження і закріплення правових норм, спрямованих на регулювання певних відносин. Дефекти джерел права проявляються у: а) юридичних дефектах змісту нормативно-правового акта, б) юридичних дефектах форми нормативно-правового акта.

Однак повернемось до проблеми термінології в досліджуваному нами праві. Неузгодженість виникає через наявність юридичних дефектів змісту джерел права, тобто суперечностей між приписами нормативно-правових актів як різної юридичної сили, так і однакових за розташуванням у ієрархії. Закон України «Про громадські об’єднання», що має деталізувати статті 36-37 Конституції України, замість того, щоб визначити дефініцію «об'єднання громадян», вводить у законодавство новий термін - «громадське об'єднання , ніяк не пояснюючи зв'язок між ними.

Як правило, коли приймається закон, особливо той, що безпосередньо спрямований на регулювання та забезпечення реалізації конкретного права, закріпленого Основним Законом, здійснюється повний аналіз законодавства на предмет необхідності внесення змін та доповнень із метою узгодження приписів нормативно-правових актів. Проаналізувавши законодавство, ми виявили той факт, що зміни торкнулись не всіх законів. Так, Закон України «Про наукову і науково-технічну діяльність» [10] визначає громадські наукові організації (громадські академії наук, наукові товариства, наукові асоціації, спілки, об'єднання тощо) як об’єднання вчених для цілеспрямованого розвитку відповідних напрямів науки, захисту фахових інтересів, координації науково-дослідної роботи, обміну досвідом. Це суперечить визначеному в законі терміну "громадські організації, «громадські спілки», вводить такі форми, як асоціації, об’єднання. Безумовно, наявність цієї статті не призведе до реєстрації «неправильної» форми об'єднання, але вводить в оману та заплутує i без того неузгоджену термінологію. Тому вважаємо за необхідне привести приписи вищезгаданого закону у відповідність до чинного Закону України «Про громадські об’єднання».

Окремого аналізу потребує Закон України «Про організації роботодавців, їхні об’єднання, права і гарантії їх діяльності» [11], який, на нашу думку, потребує повного перегляду на предмет застарілості. Варто зазначити, що, хоча цей закон визначає організацію роботодавців як неприбуткову громадську організацію, яка об’єднує роботодавців, він пасивно виключає розповсюдження на відносини, що регулюються ним, Закону України «Про громадські об’єднання», навіть не згадуючи його у статті 3 , що містить перелік законодавства, яке регулює питання створення, діяльності організацій роботодавців, їхніх об'єднань. Варто зазначити, що цей закон було прийнято пізніше, ніж Закон України «Про громадські об’єднання». Об’єднання організацій роботодавців, яке мало б за усіма законами логіки бути спілкою, визначається як неприбуткова громадська організація, яка об’єднує організації роботодавців, їхні об’єднання. У даному випадку ми можемо спостерігати, по-перше, неузгодженість, по-друге, неточність, по-третє, невизначеність приписів нормативно-правових актів. Як варіант вирішення проблеми: законодавцю варто надати особливий статус цим утворенням, оскільки навіть порядок їх створення відрізняється від процедури реєстрації громадської організації.

Третім видом юридичних дефектів залежно від елементів механізму правового регулювання є юридичні дефекти правовідносин. 3 урахуванням структури правовідносин виділяють:

- юридичні дефекти суб'єктного складу правовідносин;

- юридичні дефекти об'єкта правовідносин;

- юридичні дефекти змісту правовідносин.

Так, одним із колізійних питань досліджуваного нами права є суб'єктний склад. Відповідно до статті 36 Конституції України право на свободу об’єднання належить громадянам України. Інакше кажучи, конституційна свобода об'єднання $€$ правом фізичних осіб. На таких самих вихідних позиціях сформульовано і положення статті 314 Цивільного кодексу України, згідно з якою право на свободу об'єднання віднесено до особистих немайнових прав, що забезпечують соціальне буття фізичної особи.

При цьому, як свідчить досвід зарубіжних держав, у конституційних законах окремих країн, зокрема статті 9 Конституції Естонії [12], зафіксовано положення про те, що права, свободи та обов'язки людини і громадянина поширюються на юридичних осіб настільки, наскільки це узгоджується із загальними цілями юридичних осіб та сутністю, природою прав, свобод і обов'язків, оскільки це лише правова конструкція, через діяльність якої реалізуються воля і дії тих самих фізичних осіб.

Згідно з німецькою доктриною та відповідно до положень німецького законодавства основні права поширюються на юридичних осіб тією мірою, якою вони «за своєю суттю» підлягають щодо них застосуванню. Під час тлумачення цих слів слід виходити 3 таких міркувань: основні права повинні забезпечувати однакове ставлення до людей і просторів їхньої свободи, гарантуючи «вільний від держави» саморозвиток соціальних 
підсистем. I «юридична особа» $є$ не що інше, ніж схема для спрощення того, як, хто та за що несе відповідальність, регулюючи обов'язки і повноваження людей, що живуть в організованій спільноті [13, § 13II]. Відповідно до цього юридичні особи повинні бути включені у сферу, захищену основними правами, якщо їхня поява та діяльність є вираженням індивідуальної свободи людей, які їх створили. Також з огляду на ризик, який несуть типові наявні загрози для основних прав, видається необхідним «проникнення» захисної функції основних прав та поширення її на тих, хто стоїть за юридичною особою (персональний субстрат) [14, с. 517].

Подібну ідею «підхопив» i український законодавець (на рівні закону), надавши також i юридичним особам право на об'єднання та деякі інші конституційні права. Так, у частині 2 статті 7 Закону України «Про громадські об’єднання» зазначено, що «засновниками громадської спілки можуть бути юридичні особи приватного права, в тому числі громадські об'єднання зі статусом юридичної особи». Відповідно до статті 21 юридичні особи можуть бути учасниками цивільно-правових відносин, набувати майнові i немайнові права, проводити мирні зібрання, реалізовувати право на звернення, здійснювати інші права, не заборонені законом. Проте існує рішення Конституційного Суду України від 9 лютого 1999 року № 1-рп/99 справа № 1-7/99, в якому була сформульована позиція, що положення розділу II Конституції України «Права, свободи і обов'язки людини і громадянина», де закріплені фундаментальні права, свободи і обов'язки насамперед людини і громадянина та їх гарантії, стосуються лише фізичних осіб, а отже, не поширюються на юридичних осіб [15]. Деякі судді все ж таки висловили протилежне бачення, оприлюднивши його в окремій думці. Так, на погляд судді Скоромохи B.Є., суд у цій справі мав інтерпретувати статтю 58 Конституції України щодо поширення її положень також на юридичних осіб, оскільки до них можуть застосовуватися основні права, передбачені розділом II «Права, свободи та обов'язки людини і громадянина» Конституції України. Помилка Конституційного Суду України, на мій погляд, полягає в текстуальному слідуванні визначення сфери дії через назву розділу Конституції України. Функціонування юридичних осіб безпосередньо пов'язано зі становищем фізичних осіб, тому приписи розділу II треба тлумачити в поєднанні з положеннями розділу I, зокрема статтями 1, 3 Конституції України та ін.

Висловлюючи власне ставлення до наведених вище роздумів суддів Конституційного Суду України, зазначимо, що, дійсно, права юридичної особи є похідними від прав людини. Але варто згадати мету, заради якої створюються громад- ські об’єднання, а саме: для здійснення та захисту прав і свобод, задоволення суспільних, зокрема економічних, соціальних, культурних, екологічних та інших інтересів. Мета об'єднання визначає особливості прав та обов' язків, якими наділяється юридична особа в конкретних правовідносинах. Безумовно, юридичні особи є активними учасниками різноманітних конституційних правовідносин. Однак, як зазначає О.В. Олькіна, «конституційно-правова регламентації їхньої діяльності здійснюється нерівномірно, що негативно впливає на функціонуванні приватноправових юридичних осіб. Конституційні права юридичних осіб є похідними від прав людини, в основі їхньої правової природи лежить діалектична єдність об’єктивного і суб'єктивного права індивіда, і в цій якості зазначені права мають властивості публічності, невідчужуваності, рівної юридичної сили, гарантованості та захищеності» [16, с. 122-123]. Урегулювання питання щодо суб'єктного складу досліджуваного нами права дозволить виробити механізми ефективної взаємодії юридичних осіб з іншими учасниками правовідносин у межах правової держави.

Юридичний дефект суб'єктного складу правовідносин проявляється також у наявній колізії між положеннями статті 36 Конституції України та положеннями Закону України «Про громадські об'єднання» щодо того, хто може бути засновником та членом громадської організації. Виходячи з положень Конституції України, це громадяни України, а вищезгаданий закон визначає засновниками і членами також іноземців та осіб без громадянства. Нинішне формулювання статті 36 Конституції пояснюється тим, що в теорії право на свободу об'єднання вважається політичним. Однак варто розділяти право на створення політичної партії та громадської організації. Останні створюються для реалізації й захисту прав осіб та не беруть участі у виборах, а отже, не обмежені суб'єктним складом. Вирішення описаної вище колізії, на наш погляд, частково може бути здійснено шляхом уточнення положення статті 36 Основного Закону із приводу можливості створення та вступу до громадських організацій також іноземців та осіб без громадянства, за умов дотримання ними чинного законодавства.

Підсумовуючи вищевикладене, можна дійти висновку, що у правовому регулюванні права фізичних осіб на свободу об'єднання у громадські організації в Україні мають місце різні види юридичних дефектів: логіко-структурні у вигляді колізій, суперечностей права, прогалин; техніко-юридичні дефекти, що проявляюся в недоліках форми права внаслідок недотримання вимог нормотворчої техніки під час підготовки проектів нормативно-правових актів та включають у себе дефекти термінології, невизначеність правових 
норм, надмірну конкретизацію; юридичні дефекти джерел права, а саме: дефекти їхньої змістовної частини; юридичні дефекти правовідносин у вигляді дефекту суб'єктного складу. Безумовно, це невичерпний перелік можливих дефектів, адже Україна знаходиться на етапі формування законодавства щодо інститутів громадянського суспільства.

На підставі виявлених недоліків робимо такі висновки:

- вважаємо нагальним приведення чинного законодавства до єдиних стандартів та норм, у тому числі міжнародних, щодо яких Україна взяла зобов'язання;

- вважаємо необхідним розроблення єдиного категоріального апарату, який би давав чітке розуміння різниці понять «об’єднання громадян», «громадське об'єднання», «громадське формування», «громадська організація»;

- вбачаємо за необхідне визначити суб'єктний склад досліджуваного права, адже в даному питанні норми закону суперечать нормам Конституції України;

- невизначеним законодавчо вважаємо питання щодо належності юридичним особам конституційних прав, хоча юридична доктрина та законодавство зарубіжних країн давно розглядає юридичних осіб як носіїв деяких прав та обов'язків, адже головною метою їх створення і є реалізація прав та обов'язків;

- вважаємо за необхідне привести уточнюючі закони, зокрема Закон України «Про організації роботодавців, їхні об’єднання, права і гарантії їх діяльності», Закон України «Про наукову і науково-технічну діяльність», інші закони, що врегульовують правовідносини, які стосуються різних видів об'єднань громадян, до відповідних положень Конституції України, Закону України «Про громадські об’єднання», адже певні невизначеності та суперечності можуть стати корупціогенним фактором або приводом для зловживань;

- наголошуємо на необхідності перегляду всіх нормативно-правових актів, що стосуються реалізації права приватних осіб на об'єднання на предмет дублювань, розбіжностей, нераціонального розміщення норм.

\section{Jimepamypa}

1. Коваленко Т.О. Юридичні дефекти у правовому регулюванні земельних відносин: поняття та види. Вісник Акаделії адвокатури України. 2011. Число 2. С. 237-240. URL : http://nbuv.gov.ua/UJRN/ vaau_2011_2_42.

2. Головина С.Ю. Дефекты трудового кодекса РФ и способы их устранения. Научные труды. Российскал академия юридических наук. Вып. 8. В 3 томах. Т. 2. Москва, 2008.

3. Погребняк С.П. Колізії у законодавстві України та шляхи їх переборення. : автореф. дис. ... канд. юрид. наук. Харків : Національна юридична академія України ім. Ярослава Мудрого, 2001. 19 с.
4. Незнамова 3.А. Коллизии в уголовном праве. Екатеринбург : Издательство «Cricket», 1994. 284 с.

5. Конституція України : Закон України від 28.06.1996 № 254к/96-BP. URL: https://zakon.rada.gov. ua/laws/show $/ 254 \%$ D0 $\%$ BA $/ 96-\%$ D0 $\%$ B2 $\%$ D $1 \% 80$.

6. Про об'єднання громадян : Закон України від 16.06.1992 № 2460-XII. URL : https://zakon.rada.gov. ua/laws/main/2460-12.

7. Гаєва Н.П. Критичний аналіз Закону України «Про громадські об'єднання»: деякі міркування. Часопис Київського університету права. 2013. № 4. C. 91-95.

8. Богашева Н.В. Деякі міркування щодо Закону України «Прогромадськіоб'єднання». Юридичнийжур нал. Київ, 2012. С. 22-26. URL : http://lib.rada.gov.ua/ DocDescription?doc_id=209461.

9. Про громадські об'єднання : Закон України від 22.03.2012 № 4572-VI. URL:https://zakon.rada.gov.ua/ laws/show/4572-17.

10. Про державну реєстрацію юридичних осіб, фізичних осіб - підприємців та громадських формувань : Закон України від 15.05.2003 № 755-IV. URL : http://zakon4.rada.gov.ua/laws/show/282/95-вр.

11. Про участь громадян в охороні громадського порядку і державного кордону : Закон України від 22.06.2000№ 1835-III. URL:https://zakon.rada.gov.ua/ laws/show/1835-14.

12. Про наукову і науково-технічну діяльність : Закон України від 13.12.1991 № 1977-XII. URL : https://zakon.rada.gov.ua/laws/show/848-19/ ed20190716.

13. Про організації роботодавців, їх об’єднання, права і гарантії їх діяльності : Закон України від 22.06.2012№5026-VI. URL:https://zakon.rada.gov.ua/ laws/show/5026-17/ed20140906\#n11.

12. Конституция Эстонской Республики от 28.06.1992 RT. URL : https://goo-gl.su/5l2Fb.

13. Vgl.R. Zippelius AStL. § 13II. $143 \mathrm{f}$.

14. BVerfG, Entscheidung vom 2. Mai 1967 - 1 BvR 578/63 BVerfGE 21, 362, 369. BVerfG, Entscheidung vom 31.10.1984 - 1 BvR 35/82, 1 BvR 356/82, 1 BvR 794/82, BVerfGE 68, 193, 205 f; Tonikidis, S., Die Grundrechtsfähigkeit juristischer Personen nach Art. 19 III GG, Jura, 2012. 517-521 f.

15. Рішення Конституційного Суду України у справі за конституційним зверненням Національного банку України щодо офіційного тлумачення положення частини першої статті 58 Конституції України (справа про зворотну дію в часі законів та інших нормативно-правових актів) № 1-рп-99 від 09.02.1999. URL : https://zakon.rada.gov.ua/laws/show/v001p710-99.

16. Олькіна О.В. Юридичні особи як суб'єкти конституційний правовідносин. Вісник Харківського національного унів-ту іл. В.Н. Каразіна. 2012. № 12. Серія «Право». С. 120-123.

\section{Анотація}

Чернявська Б. В. Юридичні дефекти у правовому забезпеченні реалізації права на свободу об'єднання у громадські організації в Україні. - Стаття.

У статті автор досліджує питання дефектності права на свободу об'єднання громадян в Україні. Метою є аналіз нормативно-правового регулювання права фізичних осіб на свободу об'єднання у громадські організації на предмет виявлення наявних колізій та прогалин і вироблення відповідних рекомендацій, спрямованих на нейтралізацію цих негативних чинників.

Для початку автором було розкрито поняття «юридичний дефект» та обрано класифікацію, на підставі 
якої здійснювався подальший аналіз. Критерієм класифікації було взято особливості прояву юридичних дефектів у механізмі правового регулювання, в залежності від його елементів.

Першим видом юридичних дефектів були юридичні дефекти правових норм, а саме: логіко-структурні та техніко-юридичні. Автор загострив увагу на недосконалості категоріального (термінологічного) апарату та необхідності приведення його до єдиних стандартів, адже навіть норми Конституції та Закону «про громадські об'єднання» суперечать у цьому плані. Також автор звернув увагу на надмірну конкретизацію та невиправдану деталізацію деяких норм, що регулюють досліджувані правовідносини.

До другого виду юридичних дефектів можна віднести дефекти джерел права. Автор знаходить певні суперечності між приписами нормативно-правових актів. Автор дійшов висновку, що потребують перегляну як норми Конституції, так і норми законів, що регулюють питання реалізації права на об'єднання.

Третім видом юридичних дефектів у залежності від елементів механізму правового регулювання є юридичні дефекти правовідносин. Так, зокрема, багато колізійних питань щодо суб'єктного складу досліджуваних правовідносин. По-перше, невирішеним є питання належності деяких конституційних прав громадським об'єднанням. По-друге, існують суперечності між положеннями нормативно-правових актів щодо того, хто має право на свободу об'єднання у громадські організації.

Зроблено узагальнюючі висновки про те, що нагальним $€$ приведення чинного законодавства до єдиних стандартів та норм, у тому числі міжнародних, по відношенню до яких Україна взяла зобов'язання, а також наголошено на необхідності перегляду усіх нормативно-правових актів, що стосуються реалізації права приватних осіб на об'єднання на предмет дублювань, розбіжностей, нераціонального розміщення норм.

Ключові слова: юридичний дефект, свобода об'єднання, громадська організація, правове регулювання, суперечності.

\section{Summary}

Cherniavska $B$. $V$. Legal defects in legal regulation of the right of individuals to freedom of association in civil-society organizations in Ukraine. - Article.

The central idea of the presented article is to make an in-depth investigation of the deficiencies that arise in the sphere of citizens' right to freedom of association in Ukraine. Against this backdrop, the overall purpose of the paper is to analyze the normative framework in outlined domain in order to identify legal conflicts and gaps existing in domestic law. The aforementioned made it possible to develop appropriate recommendations designed to eliminate these normative inconsistencies.

The author reveals the essence of the concept of "legal defect". This enables her to decide which option should serve as the basis for appropriate classification criterion necessary for the identification of concrete types of legal defects. In its turn, such criterion will play a crucial role in the author's further academic quest as it provides the possibility to define the features peculiar for the legal defects that prevail today. Under this circumstances, considering the legal defects from the prism of the mechanism of legal regulation, the central criterion is the certain type of the structural element of legal defect. In view of the aforesaid, three main types of legal defects were marked out.

The first type of legal defects is the legal defects of legal norms, namely the logical-structural and technical legal defects. The author draws a special attention to the imperfections that exist in terminological and conceptual framework, illustrating once again the need for the harmonization and universalization of Ukrainian legislation (especially given the fact that there are some contradictions between the provisions stipulated in Ukrainian Constitution and the provisions enshrined in the Law on Public Associations). In addition, the focus is placed on the excessive specification and over-detailization of certain legal norms regulating the relationships in the sphere of freedom of association.

The second type of legal defects include the defects existing in legal sources. Consequently, the author detected certain contradictions between domestic regulatory legal acts. As an intermediate result, it is alleged that there is definitely a need to revise both the norms of the Constitution and the norms of laws that entrench the implementation of the right to association.

Depending on the elements of the legal regulation mechanism, the third type of legal defects is the legal defects that exist in legal relations. Particularly, there are numerous conflicts existing in regulation of parties involved in the legal relationships that arise from the freedom of association. Firstly, the issue regarding the catalogue of constitutional rights of public associations remains unresolved. Secondly, there are some contradictions between the provisions of regulatory legal acts concerning who has the right to freedom of association in civil-society organizations.

As a result, following conclusions were reached: considering the certain obligations of the Ukrainian state towards the international community, it is extremely important to bring the current legislation in line with the universal legal standards and norms. Additionally, it is emphasized on the necessity for domestic authorities to revise all regulatory legal acts that regulate relationships in the sphere of the citizens' right to freedom of association in civil-society organizations (specifically, with a view to eliminate legal overlapping, conflict of laws and thoroughly counterproductive legal engineering).

Key words: legal defects, freedom of association, civil-society organization, legal regulation mechanism, contradictions. 